\title{
FELDSPARS IN THE TERRIGENOUS SEDIMENTARY ROCKS OF ESTONIA ACCORDING TO X-RAY STRUCTURAL ANALYSIS
}

\author{
Toivo KALLASTE a and Enn PIRRUS a, b
}

a Eesti Teaduste Akadeemia Geoloogia Instituut (Institute of Geology, Estonian Academy of Sciences), Estonia pst. 7, EE-0100 Tallinn, Eesti (Estonia)

b Tallinna Tehnikaülikooli Mäenduse Instituut (Mining Institute, Tallinn Technical University), Kopli 82, EE-0004 Tallinn, Eesti (Estonia)

Received April 28, 1993; accepted September 17, 1993

Abstract. The feldspar admixture occurring in the clastic sediments of Estonia differs considerably from that found in the bedrock of the Fennoscandian shield. It contains only insignificant amounts of plagioclase, and K-feldspar is mostly represented by monoclinic orthoclase. The content of K-feldspar is higher in the lower part of the sedimentary complex lying closer to the basement. In sandstones feldspar is mainly concentrated in the grain size of $0.25-0.5 \mathrm{~mm}$. The parameter $\mathrm{Al}\left(T_{1} \mathrm{O}+T_{1} m\right)$, showing $\mathrm{Al}-\mathrm{Si}$ order in $\mathrm{K}$-feldspars, exceeds in all cases the value 0.8 characterizing the K-feldspars of magmatic and metamorphic rocks. It serves as an essential criterion for the determination of lower-temperature authigenic feldspars in rocks.

Key words: feldspar, sediments, X-ray structural analysis.

\section{INTRODUCTION}

The occurrences of authigenic K-feldspar in the Estonian bedrock (in metabentonites, Lower Ordovician argillites, and the underlying sandstones) recorded in the last years brought along the need for a closer study of the feldspar admixture in the Palaeozoic clastic rocks of the area in order to establish the conditions of authigenic mineralization using the data on mineral structures. For this purpose 20 relatively feldspar-rich samples were taken from different parts (Fig. 1) of the terrigenous complexes (Vendian-Cambrian, Devonian) of the section; the coarsesilty fraction $(0.05-0.1 \mathrm{~mm})$ was studied previously in immersion liquids. For the determination of the important structural parameters by the X-ray method we chose samples with the K-feldspar content of $20-40 \%$ (in some cases also with lower contents) in the studied fraction (Table 1). The samples were taken with the aim of getting a picture about the whole terrigenous section, basing mostly on the materials from Central Estonia (Fig. 1).

\section{METHODS AND RESULTS}

In all these samples the ratio of $\mathrm{K}$-feldspar $3.24 \AA$ reflexion to quartz $3.34 \AA$ reflexion was estimated and the plagioclase admixture was determined on the basis of $3.19 \AA$ reflexion using the diffractometer DRON-2.0. It should be noted that plagioclase was recorded only in $50 \%$ 
of the samples, whereas slight $3.19 \AA$ reflexion appeared prevailingly in finer fractions, remaining also there an order weaker than the K-feldspar reflexion. Hence we can draw the first important conclusion on the feldspar component of our bedrock: the plagioclase admixture in them is very low and random. As in the overlying Quaternary sediments (till, varved clay, deposits of the Gulf of Finland) this admixture occurs in considerably larger amounts, we may conclude that during the formation of Palaeozoic sedimentary rocks the conditions of hypergenesis were noticeably. more unfavourable for the preservation of plagioclases in the sediment.

The K-feldspar-quartz ratio in sand- and siltstones is rather regular: the amount of K-feldspar increases in coarse fractions reaching its maximum in the $0.25-0.5 \mathrm{~mm}$ fraction (Fig. 2). This regularity is observable also by chemical analyses: the $\mathrm{K}_{2} \mathrm{O}$ content increases in coarser fractions from $1.63 \%$ to $3.53 \%$ (Tõrva $87-13$ ), from $1.50 \%$ to $3.29 \%$ (Vaki $67-5$ ), and from $5.87 \%$ to $8.61 \%$ (Essu 208-3). Such a regularity might be caused by the tendency of feldspars to form complex aggregates composed of solitary grains at the first stages of sediment solidification. These complexes do not disintegrate during the preparation of samples (Plate I), being thus enriched with feldspars of coarser fractions $(>0.25 \mathrm{~mm})$. This, however, does not seem to change the general tendency.

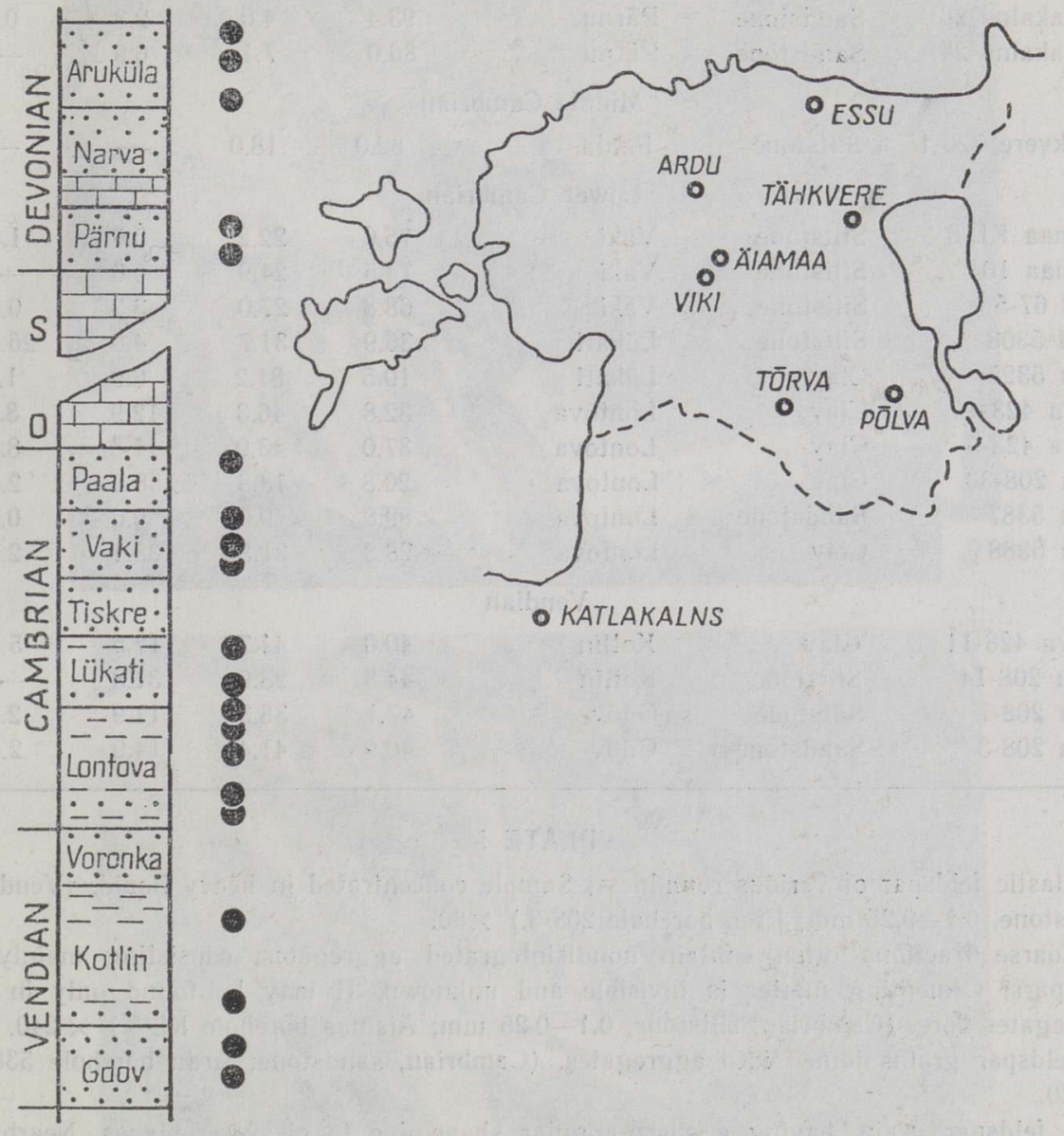

Fig. 1. Areal and stratigraphical positions of the feldspar-rich samples studied. 
The argillaceous sediments in which the feldspar content usually exceeds that of sand- and siltstones do not exhibit any clear regularity in the distribution of K-feldspars in different fractions, as here the disturbing effect of secondarily associated aggregates is even stronger.

It should be noted that higher K-feldspar contents are characteristic of Vendian rocks as well as Lontova clays. In the above-lying rocks the K-feldspar content is considerably and permanently lower. This could be explained by the extensive burial of the exposed bedrock under sediments

Table 1

List of feldspar-rich samples studied by X-ray structural method and the data of the immersion analysis of the $0.05-0.1 \mathrm{~mm}$ fraction

\begin{tabular}{|c|c|c|c|c|c|c|}
\hline \multirow{2}{*}{$\begin{array}{l}\text { Locality, } \\
\text { no. of } \\
\text { sample }\end{array}$} & \multirow{2}{*}{ Rock type } & \multirow{2}{*}{ Formation } & \multicolumn{4}{|c|}{$\begin{array}{l}\text { Composition of } 0.05-0.1 \mathrm{~mm} \\
\text { fraction, } \%\end{array}$} \\
\hline & & & Quartz & Feldspar & Mica & Varia \\
\hline \multicolumn{7}{|c|}{ Lower Devonian } \\
\hline Tõrva $87-8$ & Sandstone & Aruküla & 77.9 & 12.5 & 9.6 & - \\
\hline Törva $87+13$ & Sandstone & Aruküla & 86.8 & 9.6 & 3.6 & - \\
\hline Tõrva $87-16$ & Siltstone & Aruküla & 79.0 & 6.6 & 14.4 & 一 \\
\hline Katlakalns 26 & Sandstone & Pärnu & 93.4 & 4.0 & 2.3 & 0.3 \\
\hline Katlakalns 24 & Sandstone & Pärnu & 86.0 & 7.1 & 6.9 & 一 \\
\hline \multicolumn{7}{|c|}{ Middle Cambrian } \\
\hline Tähkvere $726-1$ & Siltstone & Paala & 82.0 & 18.0 & - & - \\
\hline \multicolumn{7}{|c|}{ Lower Cambrian } \\
\hline Aiamaa KL-5 & Siltstone & Vaki & 75.6 & 22.2 & 0.6 & 1.6 \\
\hline Aiamaa 10 & Siltstone & Vaki & 74.5 & 24.9 & 0.6 & - \\
\hline Vaki $67-5$ & Siltstone & Vaki & 68.8 & 27.0 & 3.3 & 0.9 \\
\hline Ardu 5308 & Siltstone & Lükati & 36.9 & 31.7 & 4.6 & 26.8 \\
\hline Ardu 5325 & Clay & Lükati & 10.5 & 81.2 & 6.9 & 1.4 \\
\hline Põlva $423-4$ & Clay & Lontova & 32.8 & 46.3 & 12.9 & 8.0 \\
\hline Põlva 423-5 & Clay & Lontova & 37.0 & 43.0 & 11.8 & 8.3 \\
\hline Essu 208-33 & Clay & Lontova & 20.8 & 18.8 & 58.2 & 2.2 \\
\hline Ardu 5387 & Sandstone & Lontova & 89.8 & 9.0 & 0.6 & 0.6 \\
\hline Ardu 5388 & Clay & Lontova & 28.3 & 31.3 & 38.1 & 2.3 \\
\hline \multicolumn{7}{|c|}{ Vendian } \\
\hline Põlva 423-11 & Clay & Kotlin & 40.0 & 41.7 & 12.5 & 5.8 \\
\hline Essu 208-14 & Siltstone & Kotlin & 44.3 & 23.9 & 31.8 & - \\
\hline Essu $208-7$ & Siltstone & Gdov & 47.1 & 38.3 & 11.9 & 2.7 \\
\hline Essu 208-3 & Sandstone & Gdov & 40.9 & 41.4 & 14.9 & 2.8 \\
\hline
\end{tabular}

PLATE I

1. Clastic feldspar of various roundness. Sample concentrated in heavy liquid. (Vendian, sandstone, $0.1-0.25 \mathrm{~mm}$; Essu borehole 208-3.) $\times 80$.

2. Coarse fractions often contain nondisintegrated aggregates, consisting mainly of feldspars. Cementing matter is invisible and unknown. It may be found only in the aggregates core. (Cambrian, siltstone, $0.1-0.25 \mathrm{~mm}$; Aiamaa borehole KL-5.) $\times 240$.

3. Feldspar grains joined into aggregates. (Cambrian, sandstone; Ardu borehole 5387.) $\times 420$.

4. A feldspar grain, having a sharp-angular shape due to cleavage planes. Nearby a quartz grain whose surface has been subjected to secondary processes. (Cambrian, siltstone; Aiamaa borehole KL-5.) $\times 1400$, 

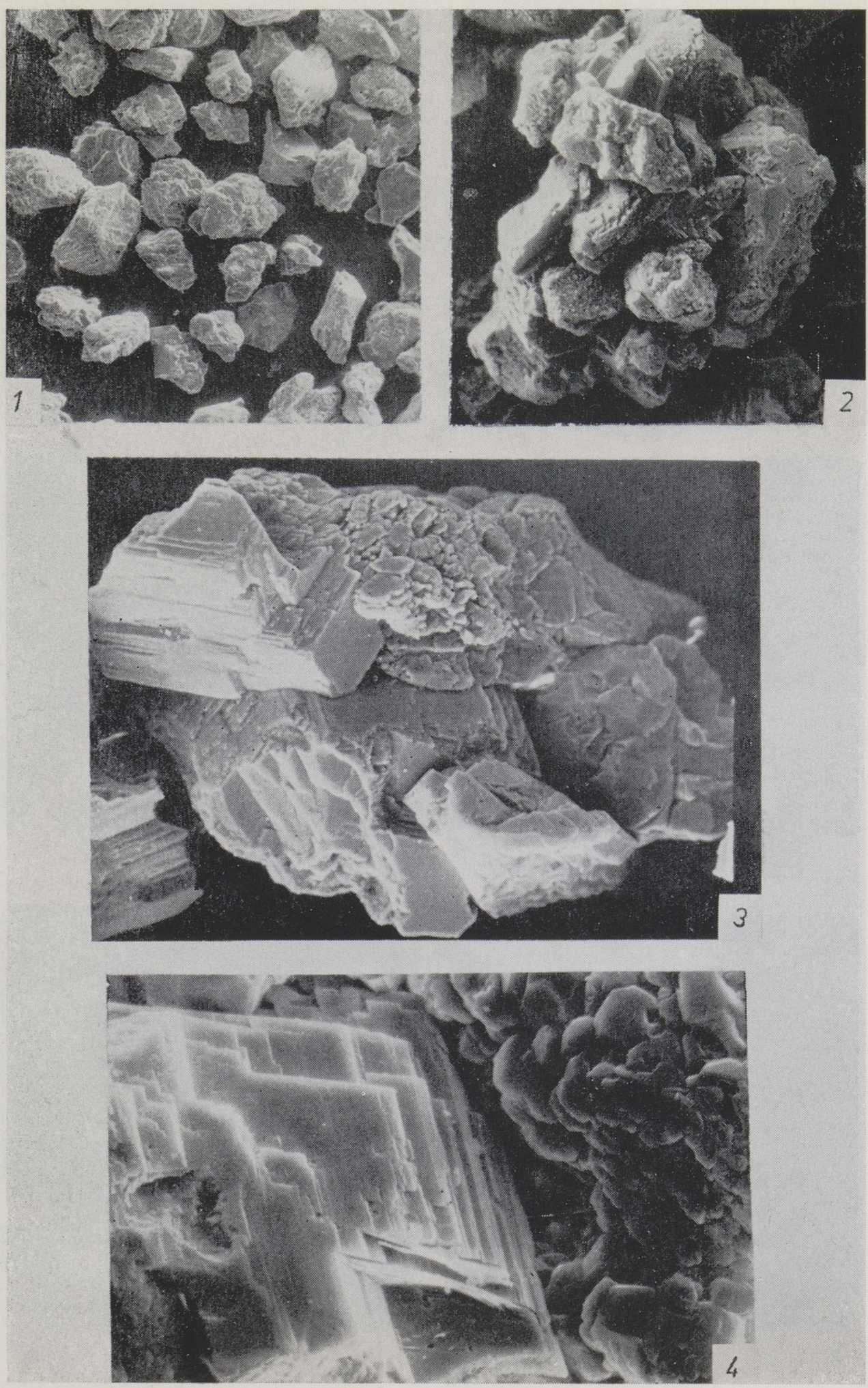

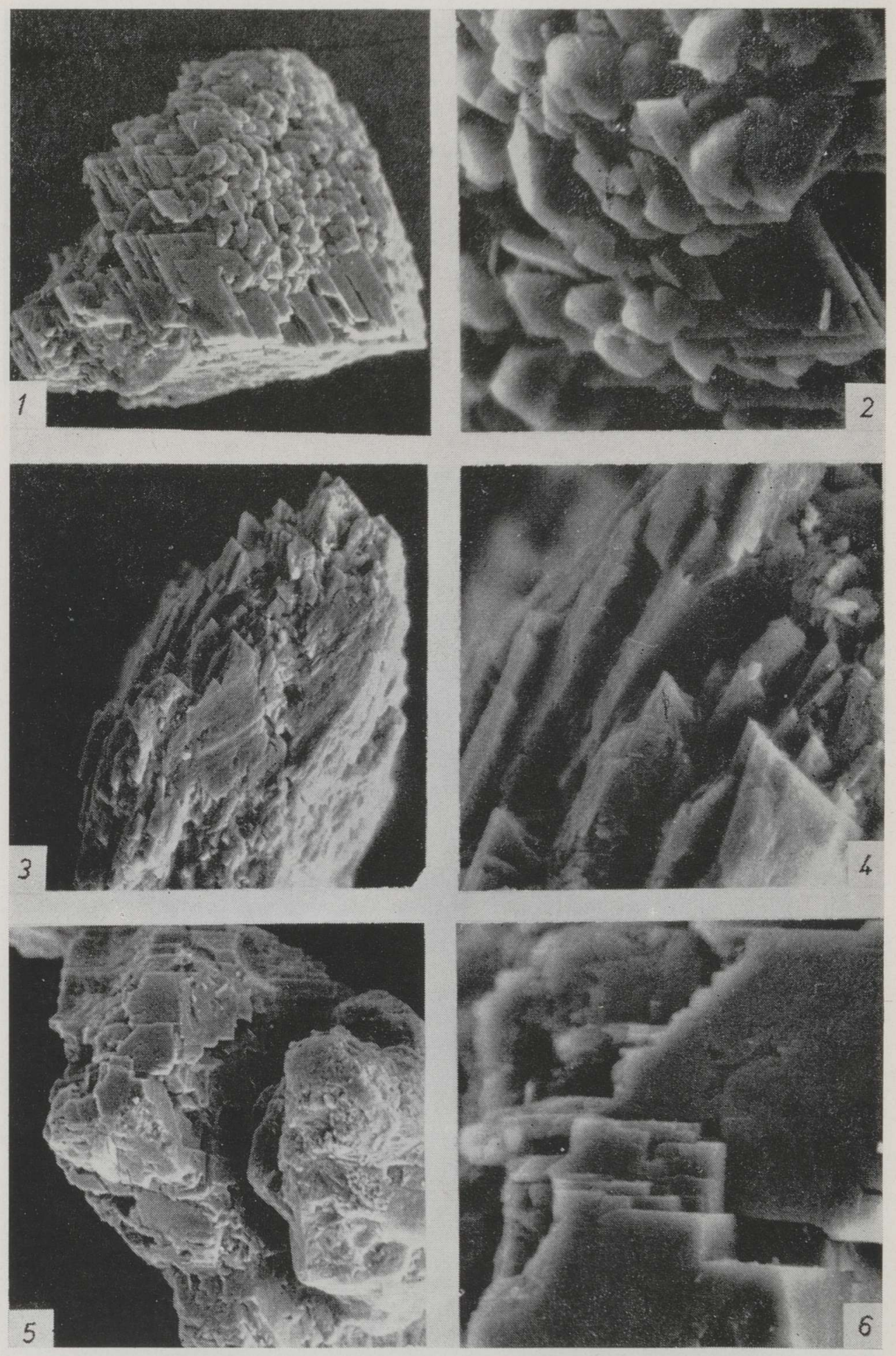
already during the first transgressions, evidenced also by other phenomena, for example the changing general characteristics of the coarse clastic admixture of sedimentary rocks (Pirrus \& Rätsep, 1977). For this reason the feldspar-rich component of the weathered basement could have been transported into this area during the sedimentation period of the clays of the Baltic Series only from the west. The influence of the basement on the sediments of the neighbouring areas was totally blocked already in post-Lontova time.

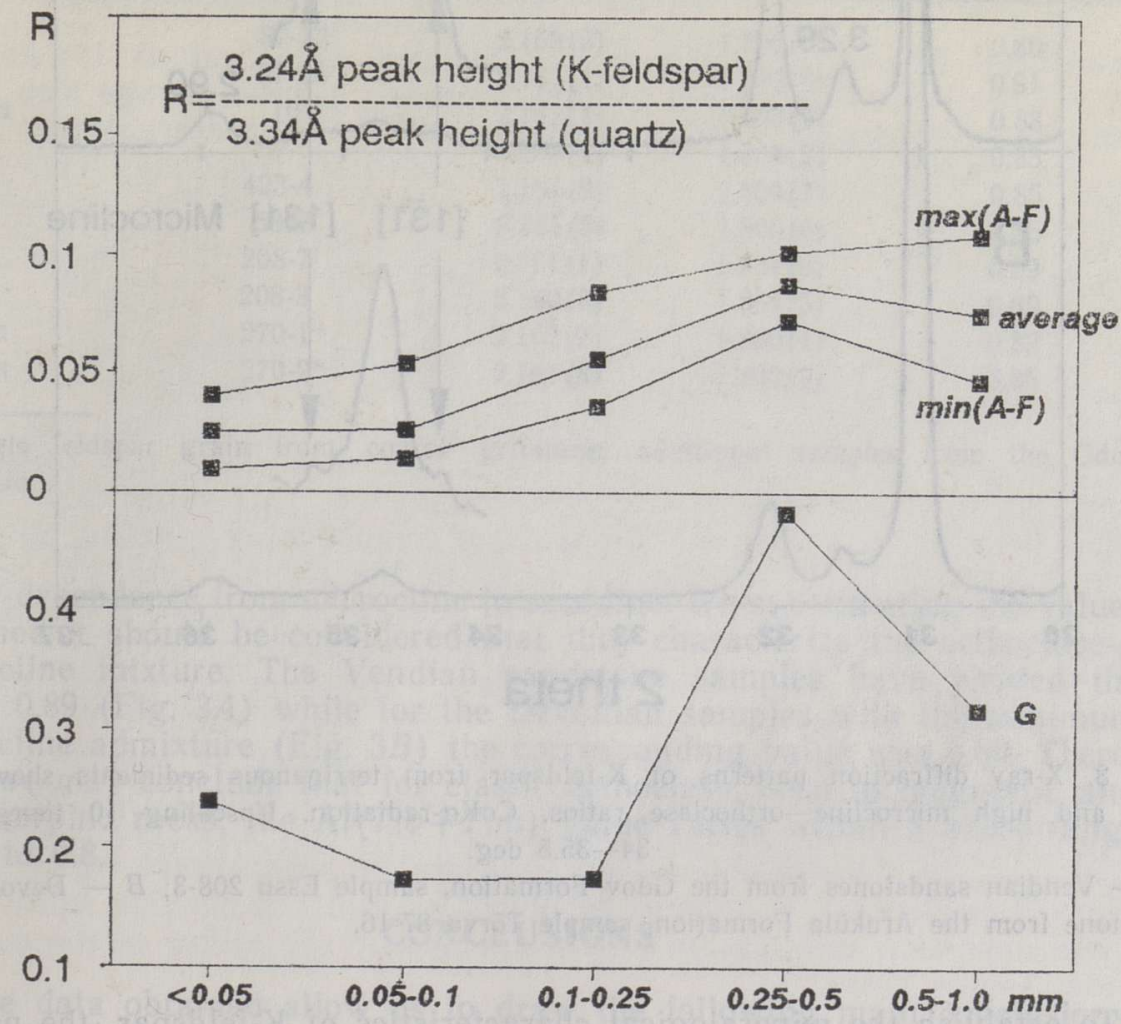

Fig. 2. Height ratio of $\mathrm{K}$-feldspar and quartz diffraction reflexions in different grainsize fractions of seven samples showing the content of K-feldspar. Above-summarized data on six samples with similar feldspar contents; below-solitary sample from the lower, near-basement part of the sedimentary complex.

$A-F$ - Tõrva 87-13, Katlakalns 24, Tähkvere 726-1, Aiamaa 10, Vaki 67-5, Ardu 5387, Essu 208-3.

\section{PLATE II}

1. Highly decomposed K-feldspar grain, occurs as cleavage forms; rhombic plates and isometric-colloform formations separate. Small amount of clay minerals. The grain shows no rounding. (Cambrian, sandstone; Ardu borehole 5387.) $\times 600$.

2. The same, $\times 2400$.

3. Slightly rounded decomposing feldspar grain: the outer surface is still determined by sharp-angled cleavage forms. Clay particles are formed in small numbers. (Vendian, sandstone; Essu borehole 208-3.) $\times 650$.

4. The same, $\times 2400$.

5. Plate-shaped feldspar grain with slight traces of rounding at the angles: the rounded surface is determined by the stepped nature of cleavage. (Devonian, siltstone; Tõrva borehole $87-16$.) $\times 350$.

6 . The same, $\times 2000$. 


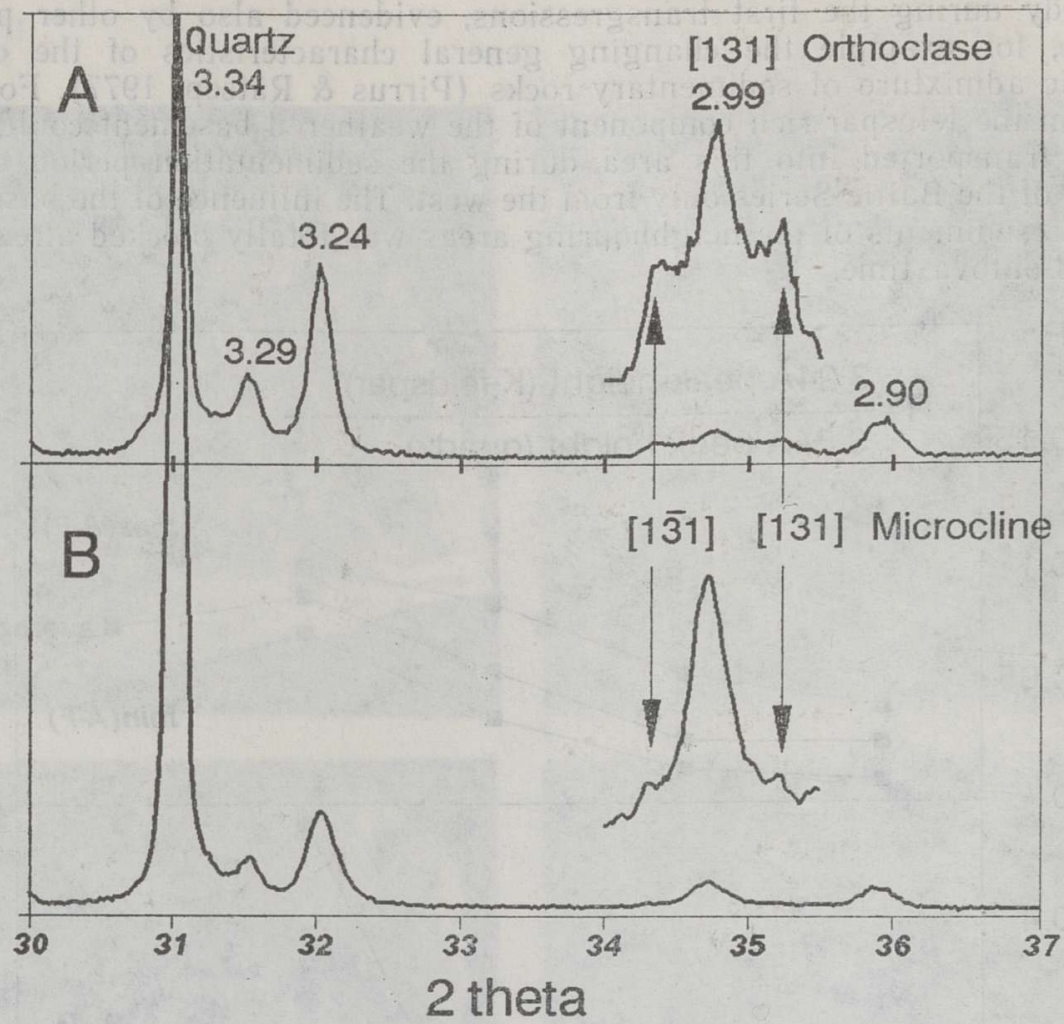

Fig. 3. X-ray diffraction patterns of K-feldspar from terrigenous sediments showing low and high microcline-orthoclase ratios. CoK $\alpha$-radiation. Upscaling 10 times at $34-35.5$ deg.

$A$ - Vendian sandstones from the Gdov Formation, sample Essu 208-3; $B$ - Devonian siltstone from the Aruküla Formation, sample Tõrva 87-16.

To establish the mineralogical characteristics of K-feldspar, the parts with its higher content were separated from the sample, using a heavy liquid consisting of bromoform and xylol. The proper density of the liquid was chosen by means of quartz and microcline control crystals. Unfortunately, this method did not suit for fine fractions as in this case the grains coagulated into undivisible complexes. Therefore mostly the $0.1-$ $0.25 \mathrm{~mm}$ fractions were processed, although several Devonian samples did not give satisfactory results in this case either.

Still, in most samples the concentration of K-feldspars was sufficient for quite accurate measurements. The analysis performed on the DRON-2.0 diffractometer showed convincingly the predominance of orthoclase in all samples. The microcline admixture is expressed only as satellites of the orthoclase 131 reflexion. Nevertheless, it exists in all samples being more abundant in the rocks of the Vendian and the Baltic series, which represent the lower part of the section (Fig. 3).

The exact positions of the K-feldspar 060 and $20 \overline{4}$ reflexions were established by means of a HZG diffractometer using the quartz occurring in the sample as a standard (Table 2). The fitting method was applied with the $K \alpha_{1}$ peak described by a symmetrical bell-shaped function and a corresponding $\mathrm{K} \alpha_{1}-\mathrm{K} \alpha_{2}$ doublet fitted to the reflexion measured. The parameter $\mathrm{Al}\left(T_{1} O+T_{1} m\right)$, characterizing the ordering of the feldspar structure, was calculated by the distances between this reflexion assuming 
Precise structural parameters of K-feldspar in the terrigenous rocks of the Estonian bedrock

(measured with a HZG-4 diffractometer)

\begin{tabular}{l|c|c|c|c}
\hline \multicolumn{1}{r}{ Locality } & Sample & $\begin{array}{c}d(060) \\
\overline{1}\end{array}$ & $\begin{array}{c}d(20 \overline{4}) \\
\bar{A}\end{array}$ & $\mathrm{Al}\left(T_{1} 0+T_{1} m\right)$ \\
\hline Tõrva & $87-13$ & $2.163(2)$ & $1.799(5)$ & 0.80 \\
Tõrva & $87-16$ & $2.163(4)$ & $1.799(9)$ & 0.81 \\
Aiamaa & 10 & $2.162(4)$ & $1.800(2)$ & 0.83 \\
Vaki & $67-5$ & $2.162(4)$ & $1.800(2)$ & 0.83 \\
Põlva & $423-4$ & $2.161(9)$ & $1.800(7)$ & 0.85 \\
Ardu & 5388 & $2.161(5)$ & $1.800(6)$ & 0.85 \\
Essu & $208-7$ & $2.161(1)$ & $1.801(9)$ & 0.89 \\
Essu & $208-3$ & $2.160(8)$ & $1.801(5)$ & 0.89 \\
Haljala & $270-1^{*}$ & $2.162(7)$ & $1.800(1)$ & 0.82 \\
Haljala & $270-2^{*}$ & $2.161(8)$ & $1.800(9)$ & 0.85
\end{tabular}

- Single feldspar grain from coarse gritstone, additional samples from the Gdov Formation.

linear dependence from microcline to sanidine. When estimating the values obtained it should be considered that they characterize the orthoclasemicrocline mixture. The Vendian sandstone samples have yielded the result 0.89 (Fig. $3 A$ ) while for the Devonian samples with the minimum microcline admixture (Fig. $3 B$ ) the corresponding value was 0.80 . Therefore, we may conclude that for clastic orthoclase, born in magmatic and metamorphic rocks, the $\mathrm{Al}\left(T_{1} O+T_{1} m\right)$ value varies within a short range close to 0.8 .

\section{CONCLUSIONS}

The data obtained allow us to draw the following main conclusions, which should be considered in the future discussion of the role of feldspars in Estonian bedrock.

1. The bedrock sediments differ in the amount and composition of feldspars considerably and regularly from magmatic and metamorphic rocks of the basement. The amount of feldspars in the granites of the Estonian basement exceeds threefold that of quartz, whereas plagioclases make up about $1 / 3$ of feldspars (Пуура et al., 1983; Кирс, 1986). Thus, in the processes of pre-sedimentation hypergenesis this ratio changes noticeably. A part of feldspars disintegrates and turns into clay minerals (Plate II). The first to disappear is plagioclase, in a number of samples even no traces of it were observed. Plagioclase disappears already in the sandstones of the Gdov Formation, lying immediately on the basement and containing the highest amounts of feldspars compared to other sediments. Naturally, in case of smaller quantities of feldspars, this decomposition process is sufficient for a total disappearance of the plagioclase admixture.

In several cases, however, the plagioclase admixture is still recorded. This could be an evidence of the growing significance of magmatic and metamorphic rocks in the inflow area of the basin, that are less affected by hypergenesis. Therefore, this area deserves attention from the geological aspect.

In most Quaternary sediments of Estonia, for example, the bottom sediments of the Gulf of Finland, the plagioclase $3.19 \AA$ peak is even 
stronger than the K-feldspar reflexion. This means that in these conditions the hypergenetic disintegration of the mineral has been minimal or that the inflow from the Finnish Precambrian outcrop areas has taken place over very short distances. During the accumulation of old sedimentary rocks climatic hypergenesis was obviously a notably more effective factor in the disintegration of clastic plagioclase.

2. As in the granites of Estonian basement K-feldspar is predominantly represented by microcline, often by varieties close to maximum

microcline (triclinicity index by the distance of reflexions $1 \overline{3} 1$ and 131 $\Delta p=0.75-0.85 ;$ Кирс, 1986 ), we may presume a great change also in the nature of $\mathrm{K}$-feldspars by the transition into the sedimentary rocks.

The predominance of orthoclase in sedimentary rocks may have different reasons. First, it may have been caused by the low resistance of microcline to weathering resulting in its selective disintegration into weathering products. Still, there may be another reason as well. Microcline crystals contain almost always albite and so a perthitic mixture is formed where the K-feldspar structure is strained (Stewart \& Wright, 1974; Bambauer, 1988; Кривоконева, 1977). By the disintegration of the less stable albite components the strain disappears and triclinic microcline is arranged, at least partly, into monoclinic orthoclase; this causes the lowering of the parameter $\operatorname{Al}\left(T_{1} O+T_{1} m\right)$ to 0.8 . This value could be the limit showing the presence of the feldspar component originating only from the magmatic and metamorphic rocks in the samples studied. Smaller values are rare and suggest a different genesis of feldspars: possible lowtemperature authigenic formation in a sedimentary rock itself.

3. The above discussions are necessary basis for the further study of the feldspar component, particularly if the X-ray structural method is used. All deviations from the above-said are worthy of special attention and their geological causes should be found out. They have also proved the usefulness of a wider application of the X-ray structural method-for the study of the distribution of feldspars in sedimentary rocks. As an expressive method, it enables to unveil several regularities which could yield important information on the changes in the inflow of the material from source areas.

\section{ACKNOWLEDGEMENTS}

The authors thank their colleagues A. Kleesment and K. Mens for providing the samples and for the processing of this material, $O$. Roos for the chemical analysis, and A. Noor for translating the text.

\section{REFERENCES}

Bambauer, H. U. 1988. Feldspäte - Ein AbriB. - Neues Jahrbuch. Miner. Abh., 158, 2, $117-188$.

Pirrus, E., Rätsep, M. 1977. Kruusaterad Eesti vanimais settekivimeis. - Eesti Loodus, $4,231-234$.

Stewart, D. B., Wright, T. L. 1974. Al/Si order and symmetry of natural alkali feldspars and the relationship of strained parameters to bulk composition. - Bull. Soc. Franc. Mineral. Cristallogr., 97, 356-377.

Кирс Ю. Э. 1986. Рентгеновское и оптическое изучение полевых шпатов эстонских раннеплатформенных калиевых гранитов. - Уч. зап. Тартуск. ун-та, 759. Литология платформенных пород Эстонии. Тр. по геологии. Тарту, 3-19. 
Кривоконева Г. К. 1977. Рентгенографическая методика определения структурного состояния щелочных полевых шпатов. - In: Рентгенография минерального сырья. М-во геологии СССР-ВИМС, Москва, 18-33.

Пуура В. А., Вахер Р. М., Клейн В. М., Коппельмаа Х. Я., Нийн М. И., Ванамб В. В., Қирс Ю. Э. 1983. Кристаллический фундамент Эстонии. Наука, Москва.

\title{
EESTI ALUSPÕHJA PURDKIVIMITE PÄEVAKIVIDEST RONTGENUURINGU ALUSEL
}

\author{
Toivo KALLASTE, Enn PIRRUS
}

On uuritud 20 päevakivirikast kivimiproovi Eesti aluspõhja erinevatest osadest. Selgus, et purdkivimite päevakivilisand erineb oluliselt peamise toiteala Fennoskandia kilbi magma- ja moondekivimite päevakivikomponendist. Peaaegu tervikuna on hävinud plagioklassid, kaaliumpäevakividest on ainuvaldavaks monokliinne ortoklass. See asjaolu viitab tugevatele hüpergeneesimuutustele materjali sissekandel vanaaegkonna veekogudesse võrreldes näiteks hilisemate kulutusprotsessidega kvaternaariajastul, mil settes säilisid ka ebapüsivad päevakivierimid.

K-päevakivide üldhulk paleosoikumi kivimites on suurim alumistes, aluskorrale lähedasemates vendi ja alamkambriumi kihtides, ülespoole nende hulk seaduspäraselt väheneb. Peamiseks päevakivide kandjaks liivakivides on fraktsioon $0,25-0,5 \mathrm{~mm}$. Kõikjal on K-päevakivi esindatud kõrge korrastusastmega erimitega $-\operatorname{Al}\left(T_{1} o+T_{1} m\right)>0,8$. See on ühtlasi tähtis taustkriteerium madalatemperatuuriliste päevakiviilmingute edasisel registreerimisel settekivimites.

\section{О ПОЛЕВЫХ ШПАТАХ В ТЕРРИГЕННЫХ ОТЛОЖЕНИЯХ ПАЛЕОЗОЯ ЭСТОНИИ ПО ДАННЫМ РЕНТГЕНОСТРУКТУРНОГО АНАЛИЗА}

\author{
Тойво КАЛЛАСТЕ, Энн ПИРРУС
}

На основе анализа 20 обогащенных полевыми шпатами проб из различных уровней осадочной толщи палеозоя установлены их характерные особенности и отличие их состава от состава полевых шпатов в материнских породах Балтийского щита. Полевые шпаты осадочных пород очень бедны плагиоклазом - минералы этой группы встречаются лишь в следовых количествах. Калиевый полевой шпат представлен главным образом моноклинным ортоклазом. Микроклин не сохранился или присутствует в осадках в незначительных количествах. Эти закономерности однозначно указывают на интенсивные процессы гипергенного изменения состава полевых шпатов в палеозое, по крайней мере по сравнению с процессами денудации пород щита в четвертичное время.

Полевые шпаты в породах палеозоя более богато представлены в отложениях венда и раннего кембрия, с тенденцией уменьшения вверх по разрезу. В песчаных отложениях они концентрируются во фракции. $0,25-0,5$ мм. По показателю упорядоченности $\mathrm{Al}\left(T_{1} O+T_{1} m\right)$ они относятся к высокотемпературным фазам $(>0,8)$, что позволяет на их фоне легко установить более низкотемпературные разновидности, аутигенно образовавшиеся на некоторых уровнях разреза палеозоя. 